\title{
Pregnant Ritual Communication in Sunda Karuhun Culture as Therapeutic Communication for Pregnant Mothers (Study of Communication Ethnography of Baduy Outside the Tribe Kanekes)
}

\author{
Ahmad Mulyana $^{1}$, Wiwin Setianingsih ${ }^{2}$ \\ \{ahmadmulyana09@gmail.com ${ }^{1}$,wiwinsh@gmail.com² ${ }^{2}$, \\ Universitas Mercu Buana, Jakarta, Indonesia ${ }^{12}$
}

\begin{abstract}
Sundanese cultural rituals have been inherent and become a unity of the Baduy Outside the community in their lives. This research study is about intercultural communication between the Baduy Outside the tribe where there are rituals that apply the principles of therapeutic communication. Each culture regulates aspects of social, economic, health, and others. In the context of health, there are rituals during the period of pregnant women until giving birth in the Baduy Outside the tribe, during the ritual period there are therapeutic communication practices that can comfort pregnant women. The purpose of this study is to find out how the principles of therapeutic communication are applied in rituals as a culture of pregnancy that must be carried out by Baduy Outside Kanekes women, any ritual that reflects the principles of therapeutic communication values that can provide comfort. This research approach is qualitative with Dell Hymes' ethnographic communication theory. The results of this study that the presence of the closest person of the mother / husband can be a sedative pregnant woman in undergoing the process of pregnancy until delivery. Inheritance of rituals about Sundanese cultural customs of pregnant women is inherited and continues to be preserved into the identity of the Baduy Outside the community. Communication practices as a form of cultural inheritance, rituals that occur in the Outer Baduy for pregnant women are a reflection of the similarity and appropriateness of the principle of purpose with therapeutic communication. So that communication can be a panacea for meetings the needs of information that can provide peace and comfort for pregnant women.
\end{abstract}

Keywords: Ethnography, Pregnancy, Sundanese Custom, Ritual

\section{Introduction}

The Indonesian state has diverse tribes, in Java there are Sundanese who have many traditions and are still held down for generations from their ancestors, these traditions take the form of rituals or beliefs about something. Talking about the Sundanese in West Java, including Banten, there is a Baduy tribe that is known to still hold the traditions of its ancestors until now without the modernization eroded, they succeeded in defending what they profess and believe in living their values, including the beliefs that lived by pregnant women in the Baduy tribe. How can a pregnant woman in the Outer Baduy tribe undergo her pregnancy in a customary law? Is there any use of an object that is considered sacred or is believed to provide certain strength during pregnancy, is there a special ritual that is lived? 
How does a pregnant woman feel during her pregnancy? Are there certain messages or meanings of the ritual? How is the communication between the pregnant woman and those closest to her to whom she expresses concerns about the pregnancy she is undergoing? In Sundanese culture, which adopts a high family system, parents or mothers usually play a very important role in giving 'elder' opinions that tend to be listened to during pregnancy.

What are the things that can make pregnant women feel comfortable during their pregnancy? whether the presence of a close relative such as a husband or mother can provide peace? Similarly, by way of performing rituals or what is believed to be hereditary in culture can give the effect of calmness. Do the Sundanese traditional rituals that are lived have values similar to the study of therapeutic communication? Therefore, researchers are interested in examining what are the ritual communication during pregnancy that must be lived by Baduy Outer Kanekes women related to the comfort obtained by pregnant women during their pregnancy? And how do the pregnancy rituals in Sundanese culture have the same therapeutic values in communication?

Rituals can be innovated or be passed on from a tradition passed down from their ancestors, how religious ritual patterns are inherited as they are without changes, or some are changed by addition and subtraction. The patterns of religious rituals are inherited as they are without any change, or some are changed by addition and subtraction [1]. All forms of communication require a shared code, a communication agent who understands and uses the code, a tool, a situation, a message, a form, a topic and an event that is raised when the message is spread. [2] The focus of attention on the ethnography of communication is communication behavior within a particular cultural theme, In ethnography communication the intended communication behavior is cultural context. [3]

Subandi in Mulyana stated "Culture, society and communication are inter-related" that between society and culture also communication has a relationship. Tomlinson still in Mulyana also stated that Culture is comprehensible as the life of human being where people build through the practices of symbolic representation. Where a culture is seen to be a part of human life, where humans build through the practice of symbolic representation. [4] The Kasepuhan Indigenous Peoples of Banten Kidul in Sukabumi is known as the "Kasepuhan community " which is a daily community that runs socio culture based on the tatali paranti karuhun (traditions of ancestral heritage) [5]. Therapeutic communication is, consciously planned communication, activities and objectives are centered on the patient's recovery. [6] According to As Homby (1974) quoted by Muhith that therapeutic is an adjective associated with the art of healing [7]. One social relationship that grows in society is actually an embodiment of therapeutic communication. That the process of a therapeutic communication transaction does not only occur at the health center, hospital, or polyclinic, but can occur daily life in the community at large. [8]

Previous research used as a reference by researchers is; The focuses of therapeutic concept the important of verbal and nonverbal communication also specific strategies which can encourage express feelings and idea of patients [9], How to do therapeutic relationship effectively to help improve nursing's understanding of self-disclosure within the context of patient/nurse relationship [10], Therapeutic listening, responding unmet needs, patient emotions and patient centeredness were key characteristic of strategies for improving therapeutic interpersonal relationship [11] overview several issues of therapeutic communication relevant for improving quality of care [12], ritual is a psychologically prepared, culturally inherited, behavioral trademark of our species [13], Dell Hymes' and the ethnography of communication [14], an approach of the ethnography of communication, perspective, and a method to and in the study of culturally distinctive means and meanings of 
communication. The approach has been used to produce hundreds of research reports about locally patterned practices of communication [15], analysis of the idea that being able to speak one's native language without errors in terms of grammar does not mean that a person is competent in the language, but it should also be noted that having a good understanding of social norms is just as important [16], traditionally speaking in an indigenous language, how ethnography speaks can usefully illuminate traditional Indigenous ways of speaking [17], a study of the wisdom of Indonesian languages, and local wisdom in civilization which will become the identity of the Indonesian nation [18].

\section{Research Method}

This study uses a post positivistic paradigm, using ethnographic communication theory looks at communication patterns, when and where, and how communication practices create a community, and the diversity of codes used by a group. The approach used in this research is a qualitative approach. extracting data is carried out through direct observation and interviews with informants determined purposive sampling. Subject study were pregnant women in the village Kanekes Leuwidamar Baduy, Banten.

\section{Results and Discussion}

Banten is a gateway province on the island of Java. Banten became the link between Java and Sumatra through the port of Merak. Located at the western end of the island of Java, the province which was originally part of West Java faces the Sunda Strait, has its capital in Serang . Baduy tribe is an in-land tribe located in the Lebak district and not far from the city of Rangkasbitung. Baduy tribe consists of: "Baduy dalam/Baduy Inside" and "The Baduy Panamping or Baduy Luar/Outer tribe" live outside the area and occupy 27 villages in the Kanekes village.

Baduy women take on their roles as wives from starting to serve their husbands, cooking, cleaning the house, washing, going to the fields and also weaving, in almost every house Baduy women have weaving skills, the results of which they can use alone or sold to tourists who come to visit the Baduy for their livelihoods. They learn to read and write by informal way. The belief of the Baduy is "Sunda Wiwitan".

\subsection{The Meaning of Cultural Values in Sundanese Indigenous Rituals in Pregnant Women in the Outer Baduy/Baduy Luar Tribe \\ The culture habits practiced by pregnant women in the Outer Baduy/Baduy Luar community have been present for decades, passed down by their ancestors. From the rituals or customary habits of pregnant women in the outer Baduy tribe, it is very full of the meaning of ancestral values that have local wisdom to be communicated or conveyed to future generations. The meaning of cultural values in Sundanese traditional rituals in pregnant women in the Baduy Luar tribal community is full of values, this is a form of existing cultural communication. Cultural communication can also be seen through symbols, artifacts, clothing or clothing that are worn by Baduy women, through gesture or body language, sign language or language that is delivered orally which is Sundanese language as their daily language.}


They live in a community environment that they created with elements of culture in it, then hereditarily passed down to their children as the next generation in society of Baduy Luar, what they inherit is actually a high-value cultural heritage as the identity of a society or a nation. Pregnant women in Baduy Luar tribes are generally the same as pregnant women in general, it's just that they live in an environment that is still thick with elements of customs, many customary rules in their daily life that regulate how they behave and behave. In the Baduy Luar tribe, they tend to be more receptive to the inclusion of culture or new things in their lives but without leaving their identity as Baduy people who hold fast to their life principles and customary rules. One example of this cultural assimilation is their openness to health workers entering their village to collect data on pregnant women and toddlers as well as welfare in health services, such as village midwives assigned to the Baduy area.

AR respondents said, that pregnant women in Baduy Luar in undergoing pregnancy have dietary restrictions, there are certain foods that are prohibited for consumption by pregnant women, pregnant women not only have food restrictions but also have behavioral restrictions. Pregnant mothers in Baduy Luar will 'nyareat' ask for spells to paraji (local people who help give birth) at 3 (three) months of pregnancy and 7 (seven) months by bringing 'seupaheun' (betel, gambier fruit and whiting) and 'kanteh' (white cloth bracelets) aiming for protection and safety for pregnant women and their fetuses, the spell will be given in a white bracelet made of material worn on their left arm or called 'kanteh'. The husband of pregnant women will pick up paraji (neang) to come to the house of the pregnant woman for ritual implementation.

In the local wisdom of the Baduy, 'Paraji' uses turmeric as one of the natural antiinflammatory treatments after childbirth, giving 'koneng' (turmeric) that is given a spell on coconut shells is given after helping the birth process of the seventh day. The third- and seventh-day designation ritual is "pereuh three days, seven days pereuh" aims to treat postpartum care by giving eye drops from leaves that have been prepared to be sought from the forest by the husband of a pregnant woman. Mothers are very instrumental in assisting during the process of pregnancy and childbirth to young mothers who are pregnant in Baduy Luar, because the transfer of knowledge and culture is hereditary from a mother, how the procedures during the process of pregnancy to delivery. By communicating everything related to customs, abstinence and things passed down from generation to generation gives a sense of comfort and calm to pregnant women. Because they believe that they have followed the existing rules and apply in the community, they also believe they will get protection and blessing for what they do.

\subsection{Communication Components in Sundanese Indigenous Rituals in Pregnant Women in the Outer Baduy/Baduy Luar Tribe.}

a. Communication agent (Pregnant women in Baduy Luar tribe and parents/ mother)

b. The form of messages conveyed in the form of verbal and nonverbal messages are twoway.

c. The contents of the message to be conveyed are about adherence to ancestors, traditional leaders, parents, respect for others, mutual respect between health workers.

d. The media used is mobile telephone.

3.3 Communication Patterns In Sundanese Indigenous Rituals For Pregnant Women In Outer Baduy/Baduy Luar Tribe.

a. Message in the form of symbols; white cloth wristband (kanteh) 
b. Message in the form of language; Sundanese language and Indonesian language as a form of daily symbolic language of the Baduy community

c. Message in the form of artifacts; the use of coconut shells

d. Message in the form of a gesture; body gestures performed communicant and communicator.

\subsection{Communication patterns that occur as follows;}

a. Primary communication patterns, the distribution of messages through a medium of symbols and sign language

b. Secondary communication patterns, the use of the second media in the form of mobile phones

c. Linear communication patterns, communication activities that occur horizontally and educatively, aim to direct, educate, provide information, provide calm, as well as a form of cultural communication

d. Circular communication patterns, conversations that occur get feedback / response back repeatedly show that the communication process occurs circularly.

Researchers also observed that primary communication patterns were the highest comfort in pregnant women compared to secondary, linear or circular communication patterns. Because the primary communication patterns communicators or parents / mothers of pregnant women can use messages verbally and nonverbally. Local wisdom is always important to pay attention to not only as a cultural preservation that needs to be preserved but also a form of way for the local community to have a culture. Social scientists recognize that culture and communication have a reciprocal relationship, like two sides of a coin. Communication behavior becomes part of culture, and in time communication also determines, maintains, develops or inherits culture. [19]

Stakeholders in this cultural ritual include; parents/ambu from pregnant women, husbands from pregnant women, in-laws or parents from the husband's side, ambu paraji(local people who help give birth), friends or relatives of pregnant women. Researchers observed that the paraji acted as one of the givers of information from the cultural transfer of ancestral customs. Ritual can be understood as a symbol system that functions to strengthen feelings and motivations strongly, and last long in humans. So that the motivations and feelings can become real [20]. People involved in the ritual of pregnant women in the Baduy Luar tribe include; 'kokolot' (traditional leader), pregnant women, parents/mothers, and husband as supervisor of traditional traditions. Rituals existed for pregnant women in the BaduyLuar tribe; that every pregnant woman who enters the 3rd and 7th month of their pregnancy will be ask for a mantra or 'nyareat' so that her pregnancy is pray for a smooth pregnancy and protected by bringing seupaheun (gambier fruit, betel, and whiting) and a white cloth for a spell bracelet (kanteh). Then there are three days pereuh and seven days pereuh (dripping eyes with drops of water leaves concoction by paraji. The husband must also bury the fetal placenta around the house with flowers and coconut oil lamps for 3 days.

Mantra is formed from two syllables, "man" (mind) and "tra" (controlling). So, the mantra is the sound that controls the mind. The mind is part of consciousness and consciousness is the energy in the human body [21]. Spells on pregnant women in the Baduy Luar tribe enter through intermediaries in white cloth bracelets (kanteh). It is understood that the ritual is a prophecy that is believed by the expectant mother that her pregnancy will be maintained, a behavior that encourages an expected pregnancy. In fact, the ritual has been transformed into an entity that can provide comfort and provide calmness for certain individuals who live it. 
Mystical reality can be interpreted that things that smell magical or mystical are believed to be part of everyday reality that can be found. So that pregnant women in the Baduy Luar tribe they understand this mystical reality as part of their lives.

The high need for these beliefs is one of the factors which until now these traditional rituals are still preserved and held fast, these traditions become part of the daily life of the people in the Baduy Luar tribe. When viewed from the religious aspect, some traditions carried out as part of the implementation of rituals in Sunda Wiwitan beliefs as the basis of their beliefs. The Baduy religious system has a belief in God Almighty and is called Sunda Wiwitan. Sunda Wiwitan's beliefs are oriented to how to live a life that glorifies simplicity (no luxury), protect yourself from the effects of modernization such as not using electricity, walls, and others. [22]

In reality, the communication of ancestral cultural heritage in the BaduyLuar tribe regarding the practice of ritual pregnant women is a parental skill passed down from generation to generation to the next generation of how to carry out a pregnancy in peace and get comfort from practicing customary rituals in force. Researchers see the value of meaning contained in this parental skill that can cause comfort for pregnant women with the same goal as a therapeutic communication that is usually done by health workers. It's just that here researchers find that from the wisdom of local culture also has the same purpose meaning of a therapeutic communication. Researchers find different formations but have the same goal. . Qureshi said that cultural differences can affect the therapeutic relationship, either indirectly or directly, [23] this did not happen in this study because the actors of communication come from the same culture, as we know it facilitates the communication process that occurs.

In fact, this is the basis for researchers conducting this research to find evidence of the phenomenon that in social life there is also therapeutic communication as the researchers found in the case of pregnant women in the Baduy Luar tribe. A cultural form of local wisdom of the local community turns out to have the same goal values as therapeutic communication carried out by health workers in general. If in the case of health workers such as doctors, midwives or nurses doing therapeutic communication with their patients through a standard operating procedure (SOP) that is standardized for them as a health worker who is an expert in their field, then in the case of local cultural wisdom the researcher found that the closest people pregnant women which are parents and her husband are also paraji they communicate with pregnant women they are also experts in their fields so they have confidence in what they are conveying to pregnant women, can show empathy, be open, listen actively, and give confidence to mothers pregnant, so this has become an art form in order to achieve maximum pregnancy health for pregnant women, because these things are done by those closest to pregnant women consciously aiming and centered.

Therapeutic communication can be in the form of verbal communication or nonverbal communication. Oral communication can be distinguished: verbal communication uses vowels, namely spoken language and verbal communication does not use vowels, namely written language. Nonverbal communication can be vocal; yelling, mumbling, or complaining and nonverbal communication does not use vowels such as nods, shaking, looks, stares, and facial expressions [24]. Researchers also observed that from the local wisdom of the culture found in the Baduy Luar tribe, giving spells to the white wristband of pregnant women (kanteh), giving pereuh from the concoction of leaves, and giving koneng (turmeric) to coconut shells that have been given a spell by paraji these become a form of non-physical culture that is part of the instrument of a therapeutic communication. Because the spells or incantations found as part of the culture in the Baduy Luar have become one with their lives as a society, they live them, understand them and believe in them. D Skillsi revealed that based 
on several studies, it is proven that local wisdom has more value. Therefore, the sustainability of local wisdom needs to be maintained and developed. This can be done through knowledge and adaptation of current technology for human survival. [25]

When an individual has high understanding and confidence, knows and understands why he is doing so there will be confidence and comfort a certainty that he found in himself, so that if this is in a pregnant woman, the pregnant woman will feel confident and know that she has undergo and do things that according to her right in accordance with prevailing cultural customs so that no worries arise during pregnancy until delivery.

\subsection{The meaning of people around pregnant women in the Outer Baduy/Baduy Luar tribe}

In the ritual research during pregnancy in the Sundanese culture of the Baduy Luar, the researcher found that the communicator as a messenger to the pregnant mother interpreted herself by acting as a health worker who was giving advice and giving information to a patient, whose compassion was shown to her condition of pregnancy, as well as informing what actions she should take, where the parents of the pregnant mother or communicator play different roles from the individual herself according to the needs she faces, as stated in the theory of the role of self-carrying. This is consistent with Erving Goffman's theory of selfcarrying role. He uses a dramatic metaphor to explain how communication agents present themselves. Everyday arrangements are seen as stages and humans are seen as players who use performance to impress the audience. When you enter any situation, then you present a presentation

\section{Conclusions}

Indigenous Sundanese culture, including rituals in it has been attached and become an integral part of society Baduy Luar in their life those are the values they profess and believe in living life and in society. Obedience to the leader or tribal leader called Jaro is something that they absolutely accept if they become part of the Baduy Luar society, because customary law is enforced and applied by the chief. Researchers found a communication as a form of cultural inheritance to the next generation in rituals such as; nyareat or ask a spell to the paraji at 3 months and 7 months of gestation to the pregnant mother of the Baduy Luar tribe, also to the peureuh 3 days and 7 days after delivery, giving koneng (turmeric) after delivery after birth give a spell before the ambu paraji, abstinence of some foods and behavior for pregnant women and new mothers, placenta planting around the house and given flowers and lighting of coconut oil lamps for 3 days by her husband.

Life in Baduy Luar is more accepting of cultural assimilation or mixing culture and technology but without leaving their identity as Baduy citizens, as well as customary law applicable in the community. The presence of the closest person to the parent or husband can be a pacifier for pregnant women in undergoing the process of pregnancy until delivery. . In the practice of communication, transferring cultural heritage, customs with rituals in the Sundanese tribe that occurs in Baduy Luar towards pregnant women and parents/mothers there are values in common with therapeutic communication although not all stages of the process in therapeutic communication are fulfilled, but the communication that occurs meets the elements of the principles and goals of therapeutic communication. So that communication 
can be a panacea for the fulfillment of the need for information that can provide peace and comfort for pregnant women in Baduy Luar.

\section{References}

[1] Abdurrahman Misno Bambang Prawiro, Pesona budaya Sunda : etnografi Kampung Naga. Yogyakarta: DEEPUBLISH, 2019.

[2] Karen A Foss Stephen W Littlejohn, Teori komunikasi. Jakarta: Salemba Humanika, 2017.

[3] Engkus Kuswaro, Etnografi komunikasi Pengantar Dan contoh penelitiannya. Bandung: Widya Padjadjaran, 2011.

[4] Hapzi ali Ahmad mulyana, "Hegemony of text on magazines for urban men as popular culture reality," Man In India, p. 532, 2018.

[5] Gurniawan Kamil Pasya, Suwarma Al Muchtar, Nursid Sumaatmadja Hermanto, "Filosofi hidup sebagai basis kearifan lokal (Studi pada kesatuan masyarakat adat kasepuhan Banten Kidul)," Jurnal Gea Vol.12, p. 1, 2012.

[6] Deddy Mulyana, Metodologi penelitian komunikasi. Bandung: Remaja Rosda Karya, 2005.

[7] Sandu siyoto Abdul muhith, Aplikasi komunikasi terapeutik nursing \& health. Yogyakarta: ANDI, 2018.

[8] Momon Sudarma, Sosiologi untuk kesehatan. Jakarta: Salemba Medika, 2008.

[9] Eugjen Sotiri, Erinda Lika Esmeralda Sherko, "Therapeutic communication," JAHR, p. 457, 2013.

[10] Cheryl Pollard Paige Steuber, "Building a therapeutic relationship: How much is too much selfdisclosure?," International Journal of Caring Sciences, p. 651, 2018.

[11] Kenneth Walsh, Jed Duff, Kim Walker Rachel Kornhaber, "Enhancing adult therapeutic interpersonal relationship in the acute health care setting: an integrative review," Journal of Multidiciplinary Healthcare, p. 537, 2016.

[12] Velea Ovidiu Popa, "Issues of therapeutic communication relevant for improving quality of care," Jurnal of medicine and life, p. 39, 2014.

[13] Cristine H Legare Rachel E Watson-Jones, "The social funtions of group rituals," Researchgate, p. 42, 2016.

[14] William Marcellino Barbara Johnstone, "Dell Hymes and the ethnography of communication," Reasearchgate, p. 1, 2014.

[15] Donal Carbaugh, "Ethnography of communication," Researchgate, p. 1, 2017.

[16] Priyanka Tripathi Aiman Reyaz, "How cultures talk: a study of Dell Hymes' ethnography of communication," Journal of Humanities and Cultural Studies R\&D, p. 1, 2016.

[17] Ochoa Richard Henne, "Sustaining and revitalizing traditional indigenous ways of speaking: an ethnography of speaking approach," Elsevier, p. 1, 2018.

[18] Tina Kartika, "Verbal communication culture and local wisdom: The value civilization of Indonesian nation," Lingua Cultura, p. 89, 2016.

[19] Jalaludin rakhmat Deddy mulyana, Komunikasi antar budaya. Bandung: PT. Remaja rosdakarya, 2010.

[20] Deddy Mulyana, Ilmu komunikasi suatu pengantar. Bandung: PT. Remaja Rosdakarya, 2008.

[21] Ananda T. Dhyanashakti, Teori Dan tuntunan praktek kriya yoga. Jakarta: PT. Gramedia pustaka utama, 2002.

[22] Djoko Adi Prasetyo, Kasnodihardjo Mara Ipa, "Praktik budaya perawatan dalam kehamilan persalinan Dan nifas pada etnik Baduy Dalam," Researchgate, p. 25, 2016.

[23] Francisco Collazos Adil Qureshi, "The Intercultural and interracial therapeutic relationship: challenges and rcommendations," International Review of Psyhiatry, p. 17, 2011.

[24] Prof Suwardi Lubis, Prof Lahmuddin Lubis Zainun, "The use of therapeutic communicaton symbol to motivate patient's healing," Journal of Humanities And Social Science (IOSR-JHSS), p. 60, 2017.

[25] Dahliani, "Local wisdom in built environment in globalization era," International Journal of Education and Research, pp. 164-165, 2015.

[26] Kiki Zakiah, "Penelitian etnografi komunikasi: tipe dan metode," MEDDIATOR, p. 182, 2008. 